\title{
Recap of the 2014 Global Communication Program Year-End Student Presentations
}

\section{Sibo Chen}

School of Communication

Simon Fraser University

The M.A. Double Degree Program in Global Communication, jointly offered by Simon Fraser University (SFU) and the Communication University of China (CUC), is the first fully integrated cohort program in Global Communication. It offers students of all nationalities with a unique experience of cross-cultural experience and cooperative learning. The Year-End Student Presentations on August 8, 2014 marked the end of the first cohort's study at SFU. This event also demonstrated the amazing accomplishments of these students through their intensive academic engagement at SFU School of Communication.

As indicated by the event's poster, the Global Communication Program has a general focus on the interactions between the "local" and the "global". As one of the most significant phenomena of the contemporary society, globalization presents a multifaceted process in which many traditional boundaries have been re-drawn and blurred. There is a general consensus among the academia that the discussions of globalization should not be limited to global economic integration. Rather, globalization should be seen as growing connections of people around the world, which has provoked a "re-spatialization" of social relations and a "re-configuration" of social geography (Giddens, 1990). As such, the questions addressed by the presenters during the event provided pivotal perspectives for us to understand how communication of the local is interwoven with that of the global.

During the event, a total of ten papers were presented and these presentations altogether shown the vigorousness, originality, and diversity of the first cohort's research. The event started with Maggie Chao's research on the Vancouver Art Gallery project. Built upon the theory of "neoliberal urbanism" (Peck, Thodore, \& Brenner, 2009), this research explores the dynamic interactions between urban transformation and cultural identity and how the new Vancouver Art Gallery project champions neo-liberal ideologies under its seemingly legitimate arguments.

The second presentation came from Yuan-Hao Zhang, in which the proliferation of western popular culture in China is examined through the lens of the "Lady Gaga phenomenon". Drawing previous research on Youth and Fandom Culture (e.g. Jekins, 1992), Zhang's paper addresses the motivations behind Chinese youngsters' worship of Lady Gaga as an idol of LGBT culture and the potential of such participatory culture being transformed into a form of political resistance.

Next, Rebeca Galindo presented an interesting research on the exhibition of Chinese films in Latin America film festivals. The global distribution of Chinese films is regarded as an important segment of China's growing soft power (Cao, 2014). Focusing on the narrative diversity of Chinese films shown in Latin America film festivals and the complex distribution issues behind them, Galindo's analaysis argues against the simplified notion that all state-approved Chinese movies are propaganda and we should "embrace" banned Chinese movies as a form of political protest.

The presentation by Vivien (Bei-Wei) Wang continued the discussion of China's artistic presentations overseas. This research analyzes two models of transnational communication of Chinese artefacts (the "top-down model" and the "bottom-up model"). The paper further explores the emergency of a third model, the "open model" (Worth, 2009) and discusses its potential of providing an alternative solution for artistic presentation.

Michael Johnston gave the fifth presentation on online gaming. As a dedicated online gamer, Johnston combines his personal interest with his research of imagined communities in virtual spaces (Morley \& Robins, 1995). He persuasively demonstrates his arguments on the local and the global phenomena in massively multiplayer online role-playing games (MMORPGs) via three case stud- 
ies: (1) geopolitical antagonism against Japan in Chinese MMORPGs, (2) MMORPGs' presentations of global and local capitalism, and (3) the local- global distinction in MMORPGs' presentations of physical space.

The presentation by Joseph Nicolaï offered an interesting historical exploration on the topic of UNESCO World Heritage Centre. Drawing on documentary research of the criteria of the World Heritage assessment process, this research criticizes the "essentialist" approach to heritage (e.g. Huntington, 1996) and advocates a "nominalist" approach to heritage. The key point of Nicolaï's argument is that cultural heritage should be understood as sites of ideological and political conflicts.

Then, Jane (Qian) Liu discussed the daily operations of CCTV-America, China Central Television's most important overseas branches. Based on a comparative study between CCTV-America and CNN on two news events (the death of Nelson Mandela and the exposure of corruption issues within CCTV), Liu's analysis suggests that the floating standpoints of CCTV-America is a result of constant conflicts between the party line and the market line (Zhao, 1998).

The eighth presentation brought the discussion back to the Vancouver Context. Investigating Chinese diaspora media through a series of focus group discussions, Vanessa Kong highlights the significance of diaspora media in reinforcing community identities and maintaining neighbourhood narratives (Ball-Rokeach, Kim, \& Matei, 2001). Her research also points out the lack of interactions between diaspora media of different ethnic communities and how this limitation may in turn reinforce ethnic boundaries.

The last two presentations both focused on the topic of reality shows. Helen (Yang) Liu looks at the increasing popularity of Korean reality shows in China and the middle class narratives embedded in this phenomenon. Similarly, Lyne Lin's talk deals with Chinese reality shows and how their grand narratives celebrates a kind of ethno-nationalist discourse, which operates transnationally to consolidate the meanings of Sinophone cultures. What connects the two presentations is their common focus of the changes of Chinese media industry in the context of emerging neo-liberal economic and social policies.

Overall, the Year-End presentations explored diversified issues (e.g. artistic representation, television programming, government policy, etc.) through the theoretical lens of cultural studies and political economy of communication. The amazing performance of the first cohort indicated the impressive progress of the Global Communication program and how it inspired the potentials of emerging scholars. 
Chen

\section{References}

Ball-Rokeach, S. J., Kim, Y., \& Matei, S. (2001). Storytelling neighbourhood: Paths to belonging in diverse urban environments. Communication Research, 28(4), 392-428.

Cao, Q. (2014). China's soft power: Formulations, contestations and communication. In Q. Cao, H. Tian \& P. Chilton (eds.), Discourse, politics and media in contemporary China (pp. 171-194). Amsterdam/Philadelphia: John Benjamins Publishing Company.

Giddens, A. (1990). The consequences of modernity. Stanford, CA: Stanford University Press.

Huntington, S. P. (1996). The clash of civilizations and the remaking of world order. New York: Simon \& Schuster.

Jenkins, H. (1992). Textual poachers: Television fans \& participatory culture. New York: Routledge.

Morley, D. \& Robins, K. (1995). Spaces of identity: Global media, electronic landscapes, and cultural boundaries. New York: Routledge.

Peck, J., Theodore, N. \& Brenner, N. (2009). Neoliberal urbanism: Models, moments, mutations. SAIS Review of International Affairs, 29(1): 49-66.

Worth, 0. (2009). Beyond world order and transnational classes: The (re)application of Gramsci in global politics. In M. McNally \& J. Schwarzmantel (eds.), Gramsci and global politics: Hegemony and resistance (pp. 19-31). London: Routledge.

Zhao, Y. (1998). Media, market, and democracy in china: Between the party line and the bottom line. Urbana, IL: University of Illinois Press. 